ADDIN, Vol. 10, No. 1, Februari 2016

\title{
RADIKALISME ATAS NAMA AGAMA: Tafsir Historis Kepemimpinan Nabi Muhammad di Madinah
}

\section{Inayatul Ulya}

Institut Pesantren Mathali'ul Falah (IPMAFA) Pati, Jawa Tengah, Indonesia

ulyain@yahoo.com

\begin{abstract}
Abstrak
Akbir-akbirini radikalisme dengan mengatasnamakan agama semakin sering terekspose melalui media dalam bentuk teror, pengeboman, beberapa aksi kekerasan dan berbagai kejahatan berbungkus agama lainnya. Agama menjadi media yang dinilai tepat untuk menjadi alasan munculnya terorisme. Agama dalam hal ini terlalu sensitif untuk mengadu domba atas nama kepentingan politik yang sebenarnya. Imbas dari gerakan radikalisme atas nama agama tersebut dapat menjadi catatan buruk karena semestinya agama itu dapat menyerukan pada kedamaian. Munculnya isu-isu dan fenomena tentang radikalisme Islam menjadi wacana transnasional yang menyudutkan Islam dan menjadi tantangan baru bagi umat Islam untuk menjawabnya. Radikalisme Islam menjadi fenomena historis sekaligus sosiologis menjadi diskursus yang banyak dibicarakan dalam wacana politik dan peradaban global. Imbas dari wacana tersebut kemudian muncul stigma-stigma yang terasa kurang nyaman bagi umat Islam. Misalnya stigma tentang gerakan Islam radikal, Islam garis keras, fundamentalisme, militan, ekstrimis, Islam kanan, sampai terorisme.
\end{abstract}

Kata Kunci: Radikalisme, Kepemimpinan, Historis. 
Inayatul Ulya

\section{Abstract}

RADICALISM IN THE NAME OF RELIGION (THE LEADERSHIP HISTORICAL INTERPRETATION OF THE PROPHET MUHAMMAD IN MEDINA): Lately the radicalism on behalf religion has been exposed more often through the media in the form of terror, bombing, some violent actions and a variety of other religion crime packaged. Religion is regarded to become a precise media as the reason for the emergence of terrorism. Religion in this matter is too sensitive for pitting on behalf of political expediency. The consequence of the radicalism movement in the name of religion can be bad record because religion should has been called for in peace. The emergence of issues and phenomena of Islamic radicalism become the transnational discourse which cornering the Islam and became a new challenge for Muslims to answer it. Islamic radicalism became a historical phenomenon and also sociological becomes a much talked in the political discourse and global civilization. The consequence of the discourse is then popped the stigma that felt less comfortable for Muslims. For example: the stigma about the Islamic radical movement, the Islamic hardliners, fundamentalism, militants, extremists, right Islam, to terrorism.

Keywords: Radicalism, Leadership, Historic.

\section{A. Pendahuluan}

Radikalisme pada dasarnya merupakan paham atau aliran yang bertujuan mengadakan perubahan atau pembaharuan secara drastis dan revolusioner dalam bidang sosial dan politik. Berawal dari sebuah aliran, kemudian radikalisme muncul sebagai sebuah gerakan yang seringkali menggunakan jargon-jargon khusus yang mengatasnamakan agama, khususnya Agama Islam. Istilah "jihad fi sabilillah", "mati syahid", "khilafah" dan "Islamic state" (negara Islam) kemudian menjadi isu populer dan sering diteriakkan untuk menggalang simpati, merekrut anggota ekstrimis atau bahkan dimanfaatkan untuk kepentingan politik tertentu. Dalam banyak hal, agama seringkali menjadi objek yang menarik dan dieksploitasi sedemikian rupa untuk merealisasikan kepentingan 
yang sebenarnya. ${ }^{1}$ Sehingga radikalisme atas nama agama semakin mencoreng nama Islam sebagai agama rạ̣matan li al-'alamin.

Munculnya isu-isu dan fenomena tentang radikalisme Islam menjadi wacana transnasional yang menyudutkan Islam dan menjadi tantangan baru bagi umat Islam untuk menjawabnya. Radikalisme Islam menjadi fenomena historis sekaligus sosiologis menjadi diskursus yang banyak dibicarakan dalam wacana politik dan peradaban global. Imbas dari wacana tersebut kemudian muncul stigma-stigma yang terasa kurang nyaman bagi umat Islam. Misalnya stigma tentang gerakan Islam radikal, Islam garis keras, fundamentalisme, militan, ekstrimis, Islam kanan, sampai terorisme.

Secara faktual stigma-stigma tersebut tidak sepenuhnya salah seiring merebaknya organisasi-organisasi tertentu yang mengatasnamakan Islam dan menggunakan kekerasan dalam setiap gerakannya misalnya al-Qaeda, Jama'ah Islamiyah, Ikhwan al-Muslimin dan yang paling fenomenal saat ini adalah ISIS (Islamic State of Iraq and Syria). Meski, aktor-aktor radikal dalam Islam tersebut merupakan oknum dengan membawa misi dan kepentingan tertentu, tetapi pada akhirnya menjadi klaim dan image negatif yang melekat pada Islam dan kaum muslim pada umumnya. Sehingga dalam hal ini, masa depan Islam turut dipertaruhkan seiring dengan perang kepentingan antara muslim radikal dan muslim moderat. ${ }^{2}$

Kajian tentang radikalisme atas nama Islam serta perilaku kaum muslim radikal hendaklah dirunut aspek historisnya, karena dalam sejarah kehidupan Nabi Muhammad saw.telah

${ }^{1}$ Eksploitasi agama dalam hal terkait gerakan radikalisme ini kemudian menjadikan Islam secara rutin dihubungkan dengan kekerasan dalam setiap berita terkait aksi radikalime dan terorisme. Sehingga hal tersebut semakin memperkuat stereotip yang dipercaya secara luas tentang klaim hubungan Islam dengan radikalisme dan terorisme. Lihat Sallomi, Perang Global Melawan Terorisme dan Tragedi Kemanusiaan, (Depok: Lentera Press, 2015), hlm. 296. Dalam konteks tersebut, apabila ditelusuri lebih jauh menunjukkan bahwa kesan yang salah terhadap Islam tersebut muncul karena faktor kebencian dan ambisi tertentu. Lihat Paul Findley, Silent No More, (USA: Amana Publications, 2003), hlm. 68

${ }^{2}$ John L Esposito, The Future of Islam (Oxford: Oxford University Press, 2010), hlm. 23 
memperkenalkan Islam sebagai agama yang cinta damai dan mengajarkan perdamaian. Islam tidak pernah membenarkan praktek kekerasan dalam menyebarluaskankan agama, paham keagamaan serta kepentingan politik tertentu. Figur Nabi Muhammad saw.. tidak hanya berperan sebagai pemimpin dalam keagamaan, tetapi juga sebagai kepala negara. Umat Islam mulai hidup bernegara setelah Nabi hijrah ke Yastrib yang kemudian berubah nama menjadi Madinah. ${ }^{3}$ Di Madinahlah untuk pertama kali lahir satu komunitas Islam yang bebas dan merdeka dibawah pimpinan Nabi terdiri dari para pengikut Nabi yang datang dari Makkah (Muhajirin) dan penduduk Madinah yang telah memeluk Islam serta yang telah mengundang Nabi untuk hijrah ke Madinah (Anshar). ${ }^{4}$

Eksistensi masyarakat Islam di Madinah, sebenarnya merupakan bagian dari suatu masyarakat majemuk. Karena diantara penduduk Madinah terdapat pula komunitas-komunitas lain, orang-orang Yahudi dan sisa-sisa suku Arab yang belum menerima Islam. Satu sisi menarik figur Nabi Muhammad sebagai kepala negara mampu menetapkan konstitusi yang dapat diterima semua pihak sebagai undang-undang dasar yang mengatur kehidupan dan hubungan antara kounitas-komunitas yang berbeda yang merupakan satu komponen masyarakat yang majemuk di Madinah. Lebih lanjut, tulisan ini difokuskan pada pembahasan mengenai akar sejarah radikalisme atas nama agama dan tafsir historis sistem politik dan sosial kepemimpinan Nabi Muhammad di Madinah.

\section{B. Pembahasan}

\section{Akar Sejarah Radikalisme atas Nama Agama a. Berawal dari Persengketaan Politik}

Dalam catatan sejarah bahwa sepeninggal Nabi Muhammad saw. posisi sebagai kepala pemerintahan di Madinah diambil alih

${ }^{3}$ Menurut Nurcholish Madjid, perubahan nama dari Yastrib menjadi Madinah pada hakekatnya adalah sebuah pernyataan niat atau proklamasi untuk mendirikan negara dan masyarakat berperadaban di kota itu. Lihat Nurcholish Madjid, "Menuju Masyarakat Madani”, dalam Jurnal Ulumul Qur'an No. 2/VII/ 1996, hlm. 51.

${ }^{4}$ Munawir Sjadzali, Islam Dan Tata Negara (Jakarta: UI Press, 1990), hlm. 10. 
oleh empat sahabat terdekat Nabi Muhammad saw., yaitu Abu Bakar, Umar bin Khattab, Usman bin Affan dan Ali bin Abi Thalib. Periode empat sahabat dekat Nabi Muhammad tersebut dikenal dengan sebutan Khulafa' al-Rasyidin yang berarti para khalifah yang mendapat petunjuk dari Allah. Meskipun keempat Khulafa' al-Rasyidin tersebut memiliki karakteristik yang berbedabeda, tetapi corak kepemimpinannya tetap konsisten terhadap apa yang dicontohkan Nabi Muhammad saw. terutama dalam sistem pemerintahan mendasarkan pada prinsip musyawarah dalam pengambilan keputusan penting yang terkait dengan kepentingan publik serta dalam hal memaknai jabatan kholifah sebagai amanah dari Allah dan pemilihannya bersifat terbuka dan tidak absolut. ${ }^{5}$

Khulafa' al-Rasyidin memulai amanah yang diembannya dalam pemerintahan dengan sistem baiat. Baiat merupakan pernyataan dan pengakuan dari rakyat untuk berjanji setia serta mengikuti kholifah yang terpilih. Baiat tersebut dilakukan setelah adanya aqd atau semacam transaksi sosial antara rakyat dan khalifah. Khalifah berjanji akan menjalankan amanahnya dengan baik sesuai perintah Allah dan rasulnya dan rakyat akan memberikan dukungan penuh pada khalifah selama khalifah berada di jalur yang benar. ${ }^{6}$ Dalam perjalanan memegang roda pemerintahan, dari khalifah pertama sampai ketiga relatif stabil, meskipun sedikit muncul konflik-konflik kecil tetap dapat terselesaikan dengan baik. Tetapi semenjak khalifah keempat, yaitu masa pemerintahan Khalifah Ali bin Abi Thalib, mulai muncul pergolakan-pergolakan yang sulit diselesaikan, dimulai dari pemberontakan yang dilakukan Thalhah, Zubair dan Aisyah yang berakhir dengan peperangan yang dikenal dengan Perang Jamal. Selain itu juga muncul pemberontakan dilakukan oleh Muawiyyah bin Abu Sufyan yang kemudian menyebabkan terjadinya Perang Shiffin. Perang Shiffin tersebut akhirnya berlanjut dengan adanya forum mediasi untuk perdamaian yang disebut dengan tabkim. Dalam tabkim

${ }^{5}$ Moh. Nur Hakim, Sejarah Peradaban Islam (Yogyakarta: UMM Pers, 2011), hlm. 44-45. Bandingkan dengan Syaikh Khalid Muhammad Khalid, 5 Khalifah Kebanggaan Islam, (Jakarta: Akbar Media, 2011), hlm. 266

${ }^{6}$ Ibid., hlm. 45 
tersebut disepakati untuk tidak melanjutkan peperangan, tetapi kedua belah pihak dapat kembali pada posisi masing-masing. Setelah adanya forum tabkim tersebut gejolak mulai timbul lagi dengan mnculnya kelompok pro dan kontra yang berakhir pada munculnya perpecahan di kalangan umat Islam menjadi tiga kelompok, yaitu kelompok pendukung Ali (Golongan Syi'ah), kelompok pendukung Muawiyyah dan kelompok yang tidak mendukung keduanya (Golongan Khawarij). ${ }^{7}$

Berdasarkan perjalanan sejarah di atas menunjukkan bahwa perpecahan umat Islam pada saat Pemerintahan Khalifah Ali tersebut memicu munculnya gerakan radikalisme dalam lembaran sejarah Islam. Berawal dari persengketaan politik yang kemudian berimbas pada pemaknaan sepihak tentang ajaran Islam itu sendiri. Pemaknaan sepihak ini dalam arti bahwa demi mencapai tujuan politisnya kemudian menghalalkan cara-cara kekerasan untuk mencapai tujuannya. ${ }^{8}$ Aksi radikal tersebut ditunjukkan oleh Golongan Khawarij yang melakukan percobaan pembunuhan kepada Ali bin Abi Thalib dan Muawiyyah bin Abu Sufyan. Golongan Khawarij mengklaim bahwa Ali bin Abi Thalib dan Muawiyyah bin Abu Sufyan telah kafir dan dianggap menyeleweng dari ajaran Islam karena terlibat dalam majlis tabkim. Sehingga menurut perspektif Kaum Khawarij, Ali bin Abi Thalib dan Muawiyyah bin Abu Sufyan harus dibunuh.

${ }^{7}$ Lihat Dedi Supriyadi, Sejarah Peradaban Islam, (Bandung: Pustaka Setia, 2008), hlm. 98-99. Bandingkan dengan Sahilun A. Nasir, Pemikiran Kalam: Teologi Islam, (Jakarta: PT. Raja Grafindo Persada, 2010), hlm. 77-78. Bandingkan juga dengan Siti Maryam dkk (ed)., Sejarah Peradaban Islam,(Yogyakarta: LESFI, 2003), hlm. 80-81. Lihat juga Ahmad al-Usairy, Sejarah Islam: Sejak. Zaman Nabi Adam bingga Abad XX (Jakarta: Akbar Media, 2009), hlm. 174-176.

${ }^{8}$ Filosof ternama Jean-Paul Sartre asal Perancis tidak hanya membenarkan dirty hands (tangan-tangan kotor) untuk mencapai tujuan politis dan menganggap pada saatnya tindakan kekerasan dapat dianggap suatu kebaikan. Justru asumsinya bahwa penggunaan kekerasan merupakan salah satu metode mencapai tujuan mulia, termasuk didalamnya adalah tujuan agama. Lihat Alwi Shihab, Islam Inklusif, (Bandung: Mizan, 1999), hlm.146. Di sisi lain, pendapat yang berbeda dari filosof lain seperti Albert Camus dan Sir Karl Popper menyatakan bahwa hampir semua agama atau idiologi adalah meringankan kesengsaraan manusia, maka penggunaan kekerasan untuk mencapai tujuan mulia tersebut tidak dapat dibenarkan. Ibid. 


\section{b. Kesalahan Memahami Konsep Jihad}

Memahami Jihad dalam konteks agama, memiliki sejarah panjang dan memiliki makna yang kompleks. Mengkaji secara cermat tentang makna jihad, maka kita harus mulai dengan melihat penggunaannya dalam literatur Muslim klasik. Selain itu secara cermat, memahami makna jihad juga dapat dilihat dari sejarah dan historiografi Islam.

Kompleksitas istilah jihad ini berdasarkan banyak hal, baik pemaknaan secara konvensional maupun pemaknaan secara modern. Pemaknaan secara konvensional, jihad cenderung diartikan dengan perang atau diistilahkan sebagai jihad besar. Makna ini menempatkan jihad pada pemaknaan historis. ${ }^{9}$ Pemaknaan secara historis ini tidak dapat diditerima apa adanya, perlu kajian mendalam terkait setting sosial dan kultur masyarakat Arab pra-Islam saat itu. ${ }^{10}$ Pemaknaan secara secara historis tersebut juga perlu digunakan sebagai pendekatan dalam memahami teks al-Qur'an dan Hadis pada saat sekarang. Sehingga tidak terjadi kesalahan penafsiran dalam memahami konsep jihad secara utuh.

Jihad dalam arti perang sebagaimana yang pernah dialami Nabi Muhammad pada saat itu hanya diperbolehkan pada sangat terpaksa ketika tidak ditemui jalan lain untuk bernegosiasi dan mencari solusi terbaik. Kondisi Nabi Muhammad pada saat itu benar-benar sebagai bentuk pertahanan diri terhadap kedzaliman, intimidasi, penindasan dan tekanan yang dilakukan oleh kaum kafir Quraisy. Maka pada waktu itu, jihad dalam arti perang telah ditempuh Nabi Muhammad saw. untuk membebaskan umat Islam demi berlakunya perdamaian dan keadilan. Konsep jihad dalam konteks tersebut adalah membebaskan umat Islam dari tirani dan penindasan.

${ }^{9}$ Lihat Asghar Ali Engineer, Liberasi Teologi Islam: Membangun Teologi Damai dalam Islam (Yogyakarta: Alinea, 2004), hlm. 100.

${ }^{10}$ Masyarakat Arab pra-Islam pada saat itu memiliki tradisi dan adat kesukuan yang mengabaikan etika. Tidak adanya aturan hukum pada saat itu mengakibatkan segala sesuatu permasalahan diselesaikan dengan jalan perang antar suku yang sering berakibat pada maraknya pertumpahan darah. Ibid. hlm. 101 
Sedangkan pemaknaan jihad secara modern, jihad diartikan sebagai perang, tetapi bukan perang fisik, tetapi perang melawan hawa nafsu ${ }^{11}$ dan berjuang, menegakkan dan memajukan agama Islam, menyuruh berbuat baik dan mencegah dari hal yang tidak baik. Sehingga di era tanpa peperangan, jihad tetap harus dilakukan sebagai kewajiban umat Islam dan sebagai ketaatan terhadap Tuhan dan agamanya. Jihad dengan pemaknaan modern ini sering disebut dengan jihad kecil karena tidak harus mengorbankan jiwa dan raga.

Jihad melawan hawa nafsu tersebut juga ada yang menyebut sebagai jihad akbarkarena sulitnya menaklukkan hawa nafsu. Dalam konteks ini jihad dimaknai sebagai upaya memaklumkan hawa nafsu sebagai musuh terbesar yang harus diperangi. ${ }^{12} \mathrm{Hal}$ tersebut sejalan dengan beberapa teks tentang jihad di dalam al-Qur'an, diantaranya Q.S. at-Taubah [9]: 41 yang artinya: "Berangkatlah kamu baik dengan rasa ringan maupun dengan rasa berat, dan berjihadlah dengan harta dan jiwamu di jalan Allah. Yang demikian itu adalah lebih baik bagimu jika kamu mengetahui'. Selain itu pada Q.S. at-Taubah [9]: 20 juga menjelaskan bahwa: "Orang-orang yang beriman dan berhijrah serta berjihad di jalan Allah dengan harta dan jiwa mereka adalah lebih tinggi derajatnya di sisi Allah. Mereka itulah orang-orang yang memperoleh kemenangan”.

Berdasarkan pemaknaan jihad berdasarkan perspektif konvensional dan modern tersebut, seringkali menimbulkan kontroversi pemahaman. Pemaknaan yang proporsional mengenai konsep jihad tersebut diungkap David Cook dalam bukunya yang berjudul Understanding Jihad dengan menjadikan dasar penelitiannya pada sumber asli, yaitu al-Qur'an. Sedangkan analisis yang digunakan menggunakan analisis sejarah Islam. Temuan dalam

${ }^{11}$ Pemaknaan jihad dalam arti melawan hawa nafsu (jihad al-nafs) juga dapat dilihat dalam pemikiran al-Ghazali dalam Kitab Ibyä' Ulum äl-Din dengan mengutip beberapa ayat al-Qur'an dan Hadits Nabi diantaranya adalah QS. an-Nisa:95 yang menjelaskan bahwa Allah melebihkan orang-orang yang berjihad dengan harta dan jiwanyaatas orang-orang yang duduk. Lihat Al-Ghazali, Ibya' Ulum al-Din, (Beirut: Dar al-Kutub al-Ilmiyah, 2001), hlm. 2:274.

${ }^{12}$ Adian Husaini, Hegemoni Kristen-Barat dalam Studi di Perguruan Tinggi (Jakarta: Gema Insani, 2006), hlm. 16. 
penelitiannya memperoleh bukti bahwa jihad berarti perjuangan internal, bukan konflik militer menurut perspektif sejarah. Dalam hasil penelitiannya David Cook juga menemukan kesalahan dengan mereka yang percaya bahwa sejak Islam secara historis disebarkan oleh pedang. Pemahaman semacam ini, akan berakibat pada pembolehan terorisme sebagai arus utama jihad Islam.

Pemaknaan jihad yang dilakukan David Cook langsung berdasarkan sumber primer, yaitu al-Qur'an dan dengan menggunakan analisis berdasarkan rentetan perjalanan sejarah Islam yang berabad-abad, maka menjadikan buku ini sebagai buku terbaik bagi pembaca yang ingin mendalami tentang jihad, kekerasan dan perluasan wilyah dalam kekuasaan Islam. Karena tidak dapat dipungkiri analisis tersebut diperlukan, karena berdasarkan fakta banyak peperangan peperangan yang terjadi dalam perjalanan sejarah Islam. Mulai dari masa Nabi Muhammad, khulafaurrasyidin, Dinasti Umayyah maupun Dinasti Umayyah. Setelah mengamati bukti dari klasik sampai zaman sekarang, dapat disimpulkan bahwa gerakan jihad yang saat ini adalah sebagai hal yang dibenarkan berdasarkan sejarah Islam klasik. ${ }^{13}$ Maka, pemaknaan jihad secara historis berbeda dengan jihad intelektual modern sehingga jihad melalui pertumpahan darah saat ini sudah tidak diperlukan lagi. Tetapi konsep jihad perlu dibangun dalam rangka merubah pola pikir umat Islam dalam upaya memajukan agama dengan melakukan hal-hal yang produktif, berani menyuruh pada kebaikan dan mencegah dari kemungkaran dengan tujuan untuk memajukan Islam dan umat Islam.

\section{Kajian Radikalisme Berdasarkan Tafsir Historis Kepemimpinan Nabi Muhammad di Madinah}

Kajian tentang radikalisme dalam perspektif sejarah dapat dirunut dari aktor-aktor sejarah yang turut mengkontruksi lahirnya sejarah Islam untuk dijadikan kajian mendalam tentang hal-hal yang dapat dijadikan pijakan historis, normatif sekaligus kontekstual terkait perilaku komunitas muslim saat ini. Isu-isu tentang radikalisme, terorisme dan gerakan-gerakannya kerap

${ }^{13}$ David Cook, Understanding Jihad (California: University of California Press, 2005), hlm. 163-165. 
disandingkan dengan Islam, sehingga perlu penelusuran sejarah yang lebih akurat terkait dengan fakta-fakta sejarah yang ada beserta tafsir terhadap fakta-fakta sejarah tersebut. Tafsir historis tersebut dapat dilakukan dengan berbagai pola pendekatan, pendekatan setting sosial dan kultural yang ada pada saat itu dapat dijadikan pisau analisis untuk menemukan kebenaran dari fakta-fakta sejarah yang telah ada.

Secara historis, Nabi Muhammad dalam posisinya sebagai Nabi dan Rasul ternyata tidak hanya sekedar membawa misi teologis saja, tetapi juga sekaligus membawa misi politis. Misi teologis diimplementasikan Nabi Muhammad saw. dengan menyeru umatnya dengan meletakkan dasar-dasar aqidah. Peletakan dasar aqidah tersebut dilakukan dengan seruan untuk bertauhid (bertuhan hanya kepada Allah). Setelah itu, misi teologis dilanjutkan dengan hal yang terkait syari'ah dan muamalah. Substansinya adalah terciptanya tuntunan moral dan akhlak yang baik bagi umat manusia. Sedangkan misi politis diimplementasikan dalam bentuk ajakan moral sekaligus penataan pada sistem dan institusi-institusi sosial dan politik.

\section{Gambaran Umum Masyarakat Madinah}

Yastrib merupakan nama lama Madinah. Sebuah kota yang penuh ketenangan dengan tanah yang subur dan air yang melimpah, dikelilingi oleh bebatuan gunung berapi yang hitam. Gunung Uhud berada di utara Madinah dan Gunung Asir di barat daya. Banyak lembah di Madinah, diantaranya adalah Wadi Batsan, Mudhainib, Mahzur dan Aqiq. ${ }^{14}$ Masyarakat Madinah pra hijrah Nabi terdiri dari komunitas Yahudi dari Bani Nadhir, Quraizhah dan Qoinuqa' serta komunitas Arab dari suku Aus dan Khazraj.

\section{a. Yahudi}

Adaperbedaan pendapat tentang asal usul komunitas Yahudi di Madinah. Apakah mereka Yahudi yang pindah ke Yastrib atau orang-orang Arab yang masuk agama Yahudi. Perbedaan pendapat serupa yang menyangkut yang menyangkut suku-suku

${ }^{14}$ Akram Dhiya'uddin Umari, Masyarakat Madani: Tinjanan historis Kehidupan zaman Nabi, (Jakarta: Gema Insani Press, 1999), hlm. 63 
Yahudi yang kecil seperti Bani Akrimah, Bani Muammar, Bani Za'ura, Bani Syathibah, Bani Jasyam, Bani Mu'awiyah, Bani Murad, Bani Qasis dan Bani Tsa'labah. ${ }^{15}$ Beberapa referensi tidak menyebutkan data statistik berapa jumlah mereka tetapi hanya menyebutkan jumlah tentara setiap suku. Bani Qoinuqa' mempunyai 700 tentara, sekitar jumlah yang sama dimiliki Bani Nadzir dan antara 700 dan 900 di Bani Quraizhah. ${ }^{16}$

Jelasnya, masyarakat Madinah sebelum kehadiran Arab didominasi oleh Yahudi baik secara ekonomi, politik maupun intelektual. Dalam bidang pertanian mereka juga membawa keahlian seperti, pola bercocok tanam kelapa saw.it, anggur, delima dan sejumlah tanaman yang menghasilkan biji-bijian.

Hal-hal lain yang terlihat pada komunitas Yahudi adalah solidaritas kesukuannya, fanatisme, kedermawanan, kesenangan terhadap puisi dan latihan-latihan mempergunakan senjata. Perasaan kesukuan sangat mendominasi komunitas Yahudi sampai batas bahwa mereka tidak dapat hidup sebagai satu kelompok agama. Sebaliknya, mereka hidup sebagai suku-suku yang berselisih dan sulit diselesaikan.

\section{b. Arab}

Suku Aus menempati daerah al-awäli (dataran tinggi) disamping Quraizhah dan Nadhir. Sementara Khazraj menempati dataran rendah Madinah, Sebagai tetangga suku Bani Qoinuqa. Daerah yang ditempati suku Aus lebih subur dibanding yang ditempati suku Khazraj. Hal ini yang menyebabkan munculnya konflik antara kedua belah pihak. ${ }^{17}$

Seiring berputarnya waktu, komunitas Arab banyak mendominasi Yastrib yang sebelumnya dikuasai Yahudi. Yahudi berupaya mempertahankan kontrol mereka atas Yastrib dengan cara memprovokasi konflik diantara suku Aus dan Khazraj. Hal tersebut berimbas pada munculnya pertempuran antara suku Aus dan Khazraj terjadi 5 tahun sebelum hijrah yang dikenal dengan

${ }^{15}$ As-Samhudi, Wafa'ul Wafa', Vol. III, hlm. 112-116; Ibnu Hisyam, Sirah, Vol. II, hlm. 259 dalam Akram Dhiya’uddin Umari, Ibid. hlm. 64

${ }^{16}$ Ibnu Hisyam, Ibid. hlm. 428 dalam Akram Dhiya'uddin Umari, Ibid.

${ }^{17}$ Ibid. hlm. 66. 
perang Bu'ats. Tetapi akhirnya mereka menyadari dan berusaha melakukan rekonsiliasi terhadap perbedaan-perbedaan antara Aus dan Khazraj. Kedua belah pihak sepakat untuk mengangkat seorang dari Khazraj sebagai Raja Yastrib. Ia adalah Abdullah bin Ubay bin Salul yang bersama keluarganya memutuskan untuk tetap netral ditengah berkecamuknya perang Bu'ats. Ini menunjukkan bahwa Arab mampu memelihara kekuasaan dan supremasinya atas Yahudi setelah perang Bu'ats.

Pada satu sisi, pertempuran antara Aus dan Khazraj menimbulkan perasaan bermusuhan diantara kedua belah pihak, tetapi pada sisi lain membangkitkan keinginan untuk hidup secara damai. Keinginan hidup secara damai itu pulalah yang memotivasi penerimaan Yatsrib terhadap kehadiran Islam, lambang persaudaraan dan kedamaian.

Pada tahun kesebelas dari awal kenabian, terjadilah suatu peristiwa yang tampaknya sederhana tetapi kemudian merupakan titik awal lahirnya satu era baru bagi Islam, yakni perjumpaan Nabi di Aqobah, Mina dengan enam orang dari suku Khazraj Yatsrib yang dating ke kota Makkah untuk haji. Mereka masuk Islam dengan memberikan kesaksian tiada tuhan selain Allah dan bahwa Nabi Muhammad adalah utusan Allah. Sementara itu kepada Nabi, mereka menyatakan bahwa di Yatsrib selalu dicekam oleh permusuhan antar golongan dan antar suku. Dan mereka mengharapkan semoga Allah mempersatukan dan merukunkan golongan-golongan dan suku-suku yang selalu bermusuhan melalui Nabi. Mereka berjanji kepada Nabi akan mengajak penduduk Yatsrib untuk masuk Islam.

Pada tahun keduabelas dari awal kenabian, dua belas orang laki-laki penduduk Yatsrib menemui Nabi di Aqobah. Mereka selain mengakui kerosulan Nabi atau masuk Islam juga berjanji kepada Nabi bahwa mereka tidak akan mempersekutukan Allah, tidak akan mencuri, tidak akan berbuat zina, tidak akan membohongi dan mengkhianati Nabi. Bai'at ini dikenal sebagai Bai'at Aqobah Pertama. ${ }^{18}$

\footnotetext{
${ }^{18}$ Munawir Sjadzali, Islam dan Tata Negara, hlm. 9.
} 
Kemudian Baiat Aqobah kedua terjadi pada tahun ketigabelas yang diikuti sebanyak tujuh puluh tiga penduduk Yatsrib yang sudah memeluk Islam. ${ }^{19}$ Mereka mengundang Nabi untuk hijrah ke Yatsrib dan menyatakan lagi pengauan mereka bahwa Nabi Muhammad adalah Nabi dan pemimpin mereka.

Sejak hijrahnya Nabi ke Madinah, membawa perubahan yang sangat mendasar dan komprehensif. Dari sudut pandang keimanan dan aqidah, merepresentasikan suatu lompatan dari penghambaan sesuatu yang nyata seperti patung-patung dan bintang-bintang yang dapat dilihat, menuju penghambaan terhadap Tuhan Yang Maha Esa yang tidak dapat digambarkan atau dipadankan dengan sesuatu apapun didunia ini. ${ }^{20}$ Dalam perilaku keseharian seseorang, Islam menghadirkan perubahan radikal karena hukum tidak hanya berdasarkan hubungan sosialnya, tetapi terdisiplinkan oleh kekuatan syariah yang memberi warna dalam segala aspek kehidupannya termasuk dalam perilaku moral dan kebiasaan. Mereka taat menjalankan sholat, puasa, zakat dan ajaran-ajaran Islam lainnya.

Struktur masyarakat Madinah baru, dibangun di atas fondasi ikatan iman dan akidah yang lebih tinggi dari solidaritas kesukuan sehingga dalam pluralitas, suku Aus, Khazraj, Yahudi dan Muhajirin dapat membangun persaudaraan dalam sebuah wadah, negara Madinah.

Berdasarkan penelusuran sejarah tentang sistem sosial yang dibangun Nabi Muhammad menunjukkan bahwa kepemimpinan Nabi Muhammad terbukti mampu mengakomodir kepentingan masyarakat yang heterogen dan multikultur dengan berbagai latar belakang yang berbeda, berbeda suku maupun berbeda agama. Pendekatan dalam sebuah komunitas sosial adalah modal utama untuk menghindarkan dari konflik dan perang kepentingan yang menjadi embrio munculnya gerakan radikal. Sehingga ketika sebuah masyarakat merasa dihargai pluralitasnya dan perbedaan multikulturalnya maka persatuan dan keharmonisan

\section{${ }^{19}$ Ibid.}

${ }^{20}$ Akram Dhiya'uddin Umari, Masyarakat Madani: Tinjauan historis Kehidupan zaman Nabi, (Jakarta: Gema Insani Press, 1999), hlm. 69. 
dalam kehidupan bersama akan terwujud. ${ }^{21}$ Karena kemampuan membendung isu-isu kesukuan, isu primordialisme dan isu sektoral dapat menekan lahirnya radikalisme.

\section{Pola Kepemimpinan Nabi Muhammad Pada Masyarakat Madinah}

Setelah Nabi Muhammad hijrah ke Madinah, maka resmilah beliau menjadi pemimpin penduduk kota itu. Babak baru dalam sejarah Islam pun dimulai. Berbeda dengan periode Makkah, pada periode Madinah Islam merupakan kekuatan politik. Ajaran Islam yang berkenaan dengan kehidupan masyarakat, banyak turun di Madinah. Nabi Muhammad mempunyai kedudukan selain kepala agama juga sebagai kepala negara. Dengan kata lain, dalam diri nabi terkumpul dua kekuasaan, kekuasaan spiritual dan kekuasaan duniawi. Kedudukannya sebagai rasul secara otomatis merupakan kepala negara. ${ }^{22}$

Dalam upaya memperkokoh masyarakat dan negara yang baru dibangun, Nabi Muhammad segera meletakkan dasar-dasar kehidupan bermasyarakat yang kemudian membentuk karakter kepemimpiannya.

Pertama, Ukhuwah Islamiyah (persaudaraan sesama muslim). Nabi mempersaudarakan antara golongan muhajirin dan anshor. ${ }^{23}$ Dengan ini diharapkan agar setiap muslim merasa terikat dalam suatu persaudaraan. Apa yang dilakukan rosulullah

${ }^{21}$ Dalam hal ini Nabi Muhammad telah mempraktekkan kepemimpinan dengan pendekatan multikultural, yaitu pendekatan dengan kesediaan menerima kelompok lain yang berbeda secara sama sebagai sebuah satu kesatuan tanpa memperdulikan latar belakang budaya, etnik, bahasa, gender, bahasa maupun agama. Artinya sebagai seorang pemimpin mampu memberi penegasan bahwa dengan segala perbedaannya, mereka diperlakukan sama di ruang publik. Pemaknaan ini sebagai pemaknaan multikulturalisme yang berarti penghargaan pada keberagaman budaya masyarakat. Lihat Scott Lash dan Mike Featherstone (ed.), Recognition and Difference: Politics, Identity, Multiculture, (London: Sage Publication, 2002), hlm. 2-6. Bandingkan dengan Cristine I Bennet, Comprehensive Multicultural Education: Theory and Practice, (USA: Simon \& Schuster Company, 2008), hlm. 84.

${ }^{22}$ Harun Nasution, Islam Ditinjau dari Berbagai Aspeknya, Jilid I (Jakarta : UI Press,1985) Cet ke 5 hlm. 101.

${ }^{23}$ Badri Yatim, Sejarah Peradaban Islam (Jakarta: Raja Grafindo Persada, 2005), hlm. 26. 
dapat menciptakan persaudaraan yang baru yaitu persaudaraan yang berdasarkan agama, menggantikan persaudaraan berdasarkan darah.

Kedua, patisipatif dan egalitarian (al-musawab) yang merupakan doktrin Islam yang amat fundamental, karena Islam tidak membedakan siapapun. Dalam menta'ati peraturan undangundang tidak ada yang lebih tinggi dari yang lain. ${ }^{24}$ Masyarakat Madinah adalah masyarakat yang majemuk yang dipersatukan oleh adanya ikatan kenegaraan. Watak partisipatif dan egaliter masyarakat pimpinan nabi diluar masalah-masalah yang termasuk tugas kerasulan beliau yang bersifat murni keagamaan seperti ibadat dan penetapan hukum ilahi dapat dilihat dari prinsip musyawarah yang diperintahkan tuhan kepadanya. ${ }^{25}$

Ketiga, hubungan persahabatan dengan pihak-pihak lain yang tidak beragama Islam. Di Madinah, disamping orang-orang Arab Islam juga terdapat golongan masyarakat yahudi dan orang-orang Arab yang masih menganut agama nenek moyang mereka. Maka agar stabilitas masyarakat dapat diwujudkan, Nabi Muhammad mengadakan ikatan perjanjian dengan mereka dalam piagam Madinah. Sebuah piagam yang menjamin kebebasan beragama orang-orang yahudi. Setiap golongan masyarakat memiliki hakhak tertentu dalam bidang politik dan keagamaan. Kemerdekaan beragama dijamin dan seluruh anggota masyarakat berkewajiban mempertahankan keamanan negeri itu dari serangan luar. ${ }^{26}$

Tafsir historis kepemimpinan Nabi Muhammad di Madinah tidak lepas dari kajian teori kekuasaan yang mana pemimpin dianggap memiliki otoritas untuk melaksanakan keinginannya. ${ }^{27}$ Dalam konteks ini, Nabi Muhammad sebagai seorang pemimpin mempunyai otoritas untuk menentukan kebijakan terkait cita-

${ }^{24}$ Artani Hasbi, Musyawarah dan Demokrasi Jakarta: Gayu Media Pratama, 2001), hlm. 35 .

${ }^{25}$ Nurcholish Madjid, Islam Kerakyatan dan Keindonesiaan (Bandung: Mizan, 1994), Cet. Ke-4, hlm. 17.

${ }^{26}$ Muhammad Husain Haekal, Sejarah Hidup Mubammad (Jakarta: Litera Antar Nusa, 1990), Cet. Ke-12, hlm. 199-205.

${ }^{27}$ Max Weber, The Theory of Social and Economic Organisation (New York: Free Press, 1947), hlm 152. 
cita bangsa dan negaranya, termasuk kebijakan-kebijakan anti radikalisme. Radikalisme dalam gerakannya juga banyak dipengaruhi dan bahkan masuk melalui kekuasaan, sehingga posisi pemimpin (penguasa) sangat menentukan untuk memperkuat ketahanan nasional bangsanya dari pengaruh radikalisme yang datangnya dari luar atau sensitivitas kebijakan melalui pendekatan otoritas untuk menangkal radikalisme yang datangnya dari dalam.

\section{Piagam Madinah Sebagai Konstitusi Negara Madinah ${ }^{28}$}

Munculnya negara Madinah yang dipimpin oleh Nabi Muhammad ditandai dengan pembuatan perjanjian tertulis pada tahun $622 \mathrm{M}$ antara Nabi dan kelompok-kelompok masyarakat yang ada di Madinah. Perjanjian tertulis itu disebut shahifat yang lebih dikenal dengan sebutan piagam madinah (mitsaq al-madinat) dan konstitusi madinah. ${ }^{29}$ Piagam tersebut memuat undangundang untuk mengatur kehidupan sosial politik bersama kaum muslim dan non muslim sebagai pemimpin mereka.

Menurut Ahmad Syafi'i Ma'arif apa yang dituangkan dalam piagam Madinah adalah penjabaran dari prinsip-prinsip kemasyarakatan yang diajarkan al-Qur'an walaupun wahyu belum selesai diturunkan atau piagam Madinah merupakan aktualisasi dari ajaran al-Qur'an dalam kehidupan sosial politik dan sosial budaya ${ }^{30}$

Teks dokumen piagam Madinah

Bismillahirrahmanirrahim

1. Ini dokumen dari Muhammad, nabi (yang mengatur hubungan) antara kaum muslim Quraisy dan Yatsrib, dan mereka yang mengikuti, bergabung, dan berjuang dengan mereka.

${ }^{28}$ Para peneliti kontemporer memposisikan dokumen piagam Madinah ini sebagai dasar studi-studi mereka tentang reformasi yang dilakukan rosulullah di Madinah.

${ }^{29}$ J. Suyuthi Pulungan, Prinsip-prinsip Pemerintahan dalam Piagam Madinab: Ditinjau dalam Pandangan al-Qur'an (Jakarta:Raja Grafindo Persada, 1996), Cet. Ke-2, hlm. 3

${ }^{30}$ Ahmad Syafi'i Ma'arif, Piagam Madinah dan Konvergensi Sosial dalam Pesantren, (Jakarta: P3M, 1986) hlm. 21- 22 
2. Mereka adalah satu komunitas (ummah) dengan mengenyampingkan semua manusia.

3. Muhajirin Quraisy, sesuai dengan adat istiadat mereka, akan membayar uang tebusan (diyah) dalam nilai uang mereka dan akan menebus tawanan-tawanan mereka dengan kebaikan dan keadilan yang umum dikalangan orang-orang beriman.

4. Bani Auf, sesuai dengan adat istiadat mereka, akan membayar uang tebusan yang biasa mereka bayar sampai kini, dan setiap bagian akan menebus tawanan-tawanan mereka dengan kebaikan dan keadilan yang umum dikalangan orang-orang beriman.

5. Banul Harits (ibnul Khazraj), sesuai dengan adat istiadat mereka, akan membayar uang tebusan yang biasa mereka bayar sampai kini, dan setiap bagian akan menebus tawanan-tawanan mereka dengan kebaikan dan keadilan.

6. Bani Sa'idah, sesuai dengan adat-istiadat mereka, akan membayar uang tebusan yang biasa mereka bayar sampai kini dan setiap bagian akan menebus tawanan-tawanan mereka dengan kebaikan dan keadilan yang umum dikalangan orang-orang beriman.

7. Bani Jusyam, sesuai dengan adat-istiadat mereka, akan membayar uang tebusan yang biasa mereka bayar sampai kini dan setiap bagian akan menebus tawanan-tawanan mereka dengan kebaikan dan keadilan yang umum dikalangan orang-orang beriman.

8. Banun Najjar, sesuai dengan adat-istiadat mereka, akan membayar uang tebusan yang biasa mereka bayar sampai kini dan setiap bagian akan menebus tawanan-tawanan mereka dengan kebaikan dan keadilan yang umum dikalangan orang-orang beriman.

9. Bani Amr bin Auf, sesuai dengan adat-istiadat mereka, akan membayar uang tebusan yang biasa mereka bayar sampai kini dan setiap bagian akan menebus tawanantawanan mereka dengan kebaikan dan keadilan yang umum dikalangan orang-orang beriman. 
10. Bani al-Nabit, sesuai dengan adat-istiadat mereka, akan membayar uang tebusan yang biasa mereka bayar sampai kini dan setiap bagian akan menebus tawanan-tawanan mereka dengan kebaikan dan keadilan yang umum dikalangan orang-orang beriman.

11. Bani al-Aus, sesuai dengan adat-istiadat mereka, akan membayar uang tebusan yang biasa mereka bayar sampai kini dan setiap bagian akan menebus tawanan-tawanan mereka dengan kebaikan dan keadilan yang umum dikalangan orang-orang beriman.

12. a. Orang-orang beriman tidak akan membiarkan orang lain dalam keadaan sengsara diantara mereka dengan tidak membayar uang tebusannya atau diyah karena kebaikannya.

b. Seorang mukmin tidak akan bersekutu melawan orang merdeka dari kalangan muslim lain.

13. Orang-orang bertakwa (al-muttaqun) akan berjuang melawan para pembrontak atau mereka yang berusaha menyebarkan ketidakadilan atau dosa atau permusuhan atau korupsi diantara orang-orang beriman, setiap orang harus melawannya kendati ia adalah anak salah seorang dari mereka sendiri.

14. Seorang mukmin tidak akan membunuh orang mukmin lain karena membela orang non mukmin, tidak juga ia minta pertolongan non mukmin untuk melawan orang mukmin.

15. Perlindungan tuhan adalah untuk seluruh umat, sebagian mereka dapat memberi pertolongan kepada orang asing atas nama mereka secara keseluruhan. Orang-orang beriman adalah sahabat dan pelindung satu sama lain dengan mengenyampingkan seluruh umat manusia.

16. Orang-orang yahudi yang mengikuti kita berhak atas pertologan dan persamaan. Mereka tidak dapat dipersalahkan dan tidak pula musuh mereka ditolong.

17. Kedamaian diantara orang-orang beriman tidak dapat dipilah-pilah. Tidak ada perdamaian ketika orang-orang beriman dalam keadaan perang di jalan Allah. Persyaratan- 
persyaratan harus adil dan sama untuk semua.

18. Dalam setiap peperangan, penunggang harus mendapat nilai tambah.

19. Orang-orang beriman harus menuntut balas atas darah orang lain sesuai dengan aturan tuhan.

20. a. Orang-orang mukmin yang bertaqwa mendapat petunjuk paling baik dan benar.

b. Orang musyrik tidak akan mengambil harta atau orang Quraisy dibawah perlindungannya dan tidak pula ia ikut campur melawan orang beriman.

21. Barang siapa terbukti bersalah membunuh orang mukmin tanpa alasan yang dapat dibenarkan, maka ia akan dikenakan retaliasi (qishash), kecuali apabila walinya setuju dengan uang tebusan atas darahnya. Dan orang-orang beriman akan mengambil tindakan tegas terhadapnya.

22. Seorang mukmin yang menyepakati dokumen ini, percaya kepada tuhan dan hari akhir, tidak boleh menolong pelaku tindak kriminal atau memberi perlindungan kepadanya. Laknat Allah dan para malaikat pada hari kiamat jika ia tetap melakukannya.

23. Apabila engkau berbeda pendapat tentang suatu masalah maka kembalikanlah pada Allah dan rasul-Nya.

24. Orang-orang yahudi akan menyumbang biaya perang sepanjang mereka berperang bersama orangorang beriman.

25. 25. Yahudi Bani Auf adalah satu komunitas dengan orang-orang beriman (bagi yahudi agama mereka dan bagi muslim agama mereka)

26. Yahudi Banun-Najjar adalah sama dengan Yahudi Bani Auf.

27. Yahudi Banul Harits adalah sama dengan Yahudi Bani Auf.

28. Yahudi Bani Sa'idah adalah sama dengan Yahudi Bani Auf.

29. Yahudi Bani Jusyam adalah sama dengan Yahudi Bani Auf. 
30. Yahudi Banul Aus adalah sama dengan Yahudi Bani Auf.

31. Yahudi Bani Tsa'labah adalah sama dengan Bani Auf, kecuali terhadap orang-orang berperilaku tidak adil dan maksiat karena sesungguhnya mereka menzalimi diri mereka dan keluarga mereka sendiri.

32. Jafnah, marga Tsa'lah, adalah sebagai diri mereka sendiri.

33. Yahudi Bani Syutaibah adalah sama dengan Yahudi Bani Auf. Kesalehan adalah perlindungan terhadap kemaksiatan.

34. Orang-orang merdeka Tsa'labah adalah sebagai diri mereka sendiri.

35. Kolega-kolega dekat yahudi adalah sebagai diri mereka sendiri.

36. a. Tidaklah mereka akan pergi perperang terlepas dari izin Muhammad.

b. Tetapi ia tidak dicegah untuk menuntut balas atas luka (penderitaan). Ia yang mambunuh orang lain tanpa peringatan membunuh dirinya sendiri dan rumah tangganya sendiri, kecuali apabila berbuat salah terhadapnya karena tuhan menerima hal tersebut.

37. a.Yahudi harus menanggung biaya mereka dan muslim juga menanggung biaya mereka. Semua pihak harus membantu yang lain melawan siapa yang menyerang orang-orang (yang menyepakati) dokumen ini. Mereka harus meminta nasehat dan konsultasi satu sama lain dan kesalehan adalah perlindungan terhadap kemaksiatan.

b. Seseorang tidak bertanggung jawab terhadap kesalahan sekutunya. Yang dizalimi harus ditolong.

38. Yahudi harus membayar bersama orang-orang beriman sepanjang perang berakhir.

39. Yaysrib akan menjadi tempat suci bagi orang-orang yang menyepakati dokumen ini.

40. Orang asing dibawah perlindungan akan seperti orang yang bertanggung jawab atas perbuatannya sendiri. 
Tidak berbuat sesuatu yang membahayakan dan tidak pula melakukan tindak kriminal.

41. Seorang wanita hanya akan diberikan perlindungan dengan izin keluarganya.

42. Jika ada pertikaian atau kontroversi yang diperkirakan akan mengakibatkan keonaran dan gangguan (trouble), hal itu harus dirujukkan kepada Allah dan Muhammad, Rasul-Nya saw.. Allah menerima apa yang dekat kepada kesalehan dan kebaikan dalam dokumen ini.

43. Quraisy dan para koleganya tidak akan diberikan perlindungan.

44. Pihak yang bertikai bertanggung jawab untuk membantu pihak lain melawan serangan apapun terhadap Yatsrib.

45. a.Jika mereka diminta untuk membuat perdamaian atau menegakkannya, mereka harus melakukan itu dan jika mereka menuntut hal serupa terhadap orang-orang beriman, mereka juga harus melakukannya, kecuali apabila dalam situasi pertempuran demi agama.

46. b. Setiap orang akan memperoleh bagian dari faksi yang ia berasal darinya.

47. Yahudi Aus, orang-orang merdeka dari kalangan mereka, memiliki posisi yang sama dengan orang-orang yang menyepakati dokumen ini dan loyalitas yang sama dengan orang-orang yang menyepakati dokumen ini. Kesalehan adalah perlindungan melawan kemaksiatan:setiap orang bertanggung jawab atas perbuatannya. Tuhan menyetujui dokumen ini.

48. Dokumen ini tidak akan melindungi orang yang tidak adil dan berbuat maksiat. Orang yang maju ke medan perang adalah aman dan orang yang diam dirumahnya juga aman, kecuali apabila berbuat zalim atau maksiat. Tuhan adalah pelindung orang-orang saleh dan berkesadaran ketuhanan, dan Muhammad adalah utusan Allah. ${ }^{31}$

Merujuk pada piagam Madinah tersebut di atas, kalau diteliti dengan cermat terdapat prinsip-prinsip yang terkandung

${ }^{31}$ Akram Dhiya'uddin Umari. Op. Cit. hlm.118-122 
didalamnya yaitu prinsip persamaan umat dan persatuan, kebebasan, toleransi beragama, tolong menolong, membela yang teraniaya, musyawarah, keadilan, persamaan hak dan kewajiban, hidup bertetangga, pertahanan, perdamaian, amar ma'ruf dan nahi munkar, ketakwaan dan kepemimpinan.

Maka menurut Muhammad Husein Haikal bahwa berdasarkan piagam Madinah tersebut nabi telah membawa undang-undang baru sebagai pedoman dasar bagi pengaturan tingkah laku manusia dalam kehidupan dan pergaulan dengan sesamanya. Untuk selanjutnya menjadi pijakan dan inti bagi pengembangan sistem politik. $^{32}$

Piagam Madinah dalam catatan sejarah mampu menjadi pedoman yuridis bagi warga di Madinah saat itu. Nabi Muhammad saw. dalam hal ini mampu menyatukan orientasi hukum negaranya dengan konstitusi yang dapat mengakomodir komunitas masyarakat dari berbagai pihak. Karena di Madinah tidak hanya komunitas muslim saja tapi juga banyak komunitas agama lain, sehingga dalam teori otoritas menyatakan bahwa kekuasaan bersumber pada keteraturan normatif (normative order), keteraturan moral dalam kehidupan sosial dan menjadi karakteristik yang melekat dari teori konsesus. ${ }^{33}$ Dalam konteks radikalisme, menekankan pada fungsi konstitusi adalah pada kekuatan untuk memaksa dan menaati. Tetapiakan lebih maksimal lagi ketika berlakunya sebuah konstitusi tidak sekedar didasarkan pada pemaksaan tetapi lebih sebagai kesadaran untuk mentaati.

\section{Terbentuknya Masyarakat Madani (Civil Society)}

Masyarakat madani (civil society) dalam arti masyarakat berbudaya adalah suatu masyarakat yang saling menghargai nilai-nilai sosial kemanusiaan. ${ }^{34}$ Disisi lain masyarakat madani didefinisi merupakan idealisasi tentang suatu masyarakat yang

${ }^{32}$ Muhammad Husein Haikal, Al-ḅuküumat al-Islamiyyat, (Mesir : Dar al-Ma’arif, t.th.) hlm. 32

${ }^{33}$ David Berry, Pokok-Pokok Pikiran dalam Sosiologi (Jakarta: Raja Grafindo Persada, 1995), hlm. 197

${ }^{34}$ Adi Surya Culla, Masyarakat Madani: Pemikiran, Teori dan Relevansinya dengan Cita-cita Reformasi (Jakarta: Raja Grafindo Persada, 2002), hlm. 3 
mandiri secara politik, sosial dan ekonomi. Artinya, masyarakat dapat memperoleh dan mempertahankan hak-hak mereka dan bersama pula memperjuangkan kepentingan mereka yang sah sehingga tidak dimanipulasi negara. ${ }^{35}$

Konsep masyarakat madani bila ditinjau dari segi nilai-nilai Islam merupakan sebuah gagasan yang sangat islami. Sejarah telah mencatat bahwa masyarakat madani pernah dibangun rosulullah ketika beliau mendirikan komunitas muslim di kota Madinah.

Di kota Madinah Nabi Muhammad membangun masyarakat berperadaban berlandaskan ajaran Islam, masyarakat yang bertaqwa kepada tuhan yang maha esa. Masyarakat madani yang dibangun Nabi Muhammad saw. tersebut bercirikan antara lain: egalitarianisme, penghargaan kepada manusia berdasarkan prestasi (bukan prestise seperti keturunan, kesukuan, ras dll.), keterbukaan partisipasi seluruh anggota masyarakat dan ketentuan kepemimpinan melalui pemilihan umum bukan berdasarkan keturunan. Semua berpangkal pada pandangan hidup berketuhanan dengan konskwensi tindakan kebaikan kepada sesama manusia. Masyarakat madani tegak berdiri di atas landasan keadilan yang antara lain bersendikan keteguhan berpegang pada hukum. ${ }^{36}$

Dalam merealisasikan masyarakat madani seperti konsep di atas diperlukan manusia -manusia yang secara pribadi berpandangan hidup dengan semangat ketuhanan dengan implikasi tindakan kebaikan kepada sesama manusia. Dan dalam hal ini Nabi Muhammad saw. sebagai kepala negara telah memberikan keteladanan dalam mewujudkan suatu masyarakat seperti ciri-ciri masyarakat madani di atas.

Dalam rangka menegakkan supremasi hukum dan keadilan misalnya, Nabi Muhammad saw. tidak membedakan antara semua orang. Sekiranya saja fatimah putrid Nabi melakukan kejahatan maka ia akan dihukum sesuai dengan ketentuan yang berlaku.

${ }^{35}$ Jamal Syarif Iberani, Mengenal Islam (Jakarta: El-Kahfi, 2003), hlm. 208

36 Ahmad Gaus AF, "Masyarakat Madani Warisan Nabi Muhammad Saw", Dalam Nurcholis Majid, Kehampaan Spiritual Masyarakat Modern : Respon dan Transformasi Nilai-Nilai Islam Menuju Masyarakat Madani (Jakarta : Media Cita, 2000) hlm. 323 
Masyarakatmadanimembutuhkanadanyapribadiyangdapat mengaplikasikan konsep iman dan sekaligus amal sholih dalam Islam. Karena komitmen pribadi saja tidak cukup, tetapi harus diiringi tindakan nyata yang terealisir dalam bentuk amal sholih. Tindakan itu harus diterapkan dalam kehidupan bermasyarakat dalam tatanan kehidupan kolektif yang memberi peluang adanya pengawasan. ${ }^{37}$ Selain itu masyarakat madani sebagai masyarakat yang ideal juga memiliki karakteristik sebagai berikut:

a. Bertuhan, artinya bahwa masyarakat tersebut adalah masyarakat yang beragama, yang mengakui adanya tuhan dan menempatkan hukum tuhan sebagai landasan yang mengatur kehidupan sosial

b. Damai, artinya masing-masing elmen masyarakat baik secara individu maupun secara kelompok menghormati fihak lain secara adil

c. Tolong menolong tanpa mencampuri urusan internal individu lain.

d. Toleran, artinya tidak mencampuri urusan pribadi pihak lain yang telah diberikan oleh Allah sebagai kebebasan manusia dan tidak merasa terganggu oleh aktivitas orang lain yang berbeda tersebut.

e. Keseimbangan antara hak dan kewajiban sosial. Hal ini berlaku pada seluruh aspek kehidupan sosial, sehingga tidak ada kelompok sosial tertentu yang diistemewakan.

f. Berperadaban tinggi, artinya masyarakat tersebutmemiliki kecintaan terhadap ilmu pengetahuan dan memanfaatkan kemajuan ilmu pengetahuan untuk kemaslahatan hidup manusia.

g. Berakhlak mulia. Hal ini sangat terpengaruh aspek ketuhanan dalam aplikasi akhlak agar tidak terjebak pada konsep akhlak yang relatif. ${ }^{38}$

Kajian historis tentang masyarakat madani yang dibangun Nabi Muhammad saw. menunjukkan kesuksesan Nabi [103]: 3 .

${ }^{37}$ Hal tersebut sama persis dengan konsep yang ditawarkan Q.S. al-Ashri

${ }^{38}$ Akram Dhiya'uddin Umar, Masyarakat Madani. hlm. 210-212 
Muhammad saw. dalam membentuk sistem politik sekaligus sistem sosial di Madinah saat itu. Tentunya dengan memaksimalkan partisipasi aktif dari berbagai komponendalam masyarakat dapat menahan dan mencegah masuknya radikalisme dalam sebuah kelompok sosial.

\section{Simpulan}

Radikalisme dengan mengatasnamakan agama semakin sering terekspose melalui media dalam bentuk teror, pengeboman, beberapa aksi kekerasan dan berbagai kejahatan berbungkus agama lainnya. Agama menjadi media yang dinilai tepat untuk menjadi alasan munculnya terorisme. Agama dalam hal ini terlalu sensitif untuk mengadu domba atas nama kepentingan politik yang sebenarnya. Imbas dari gerakan radikalisme atas nama agama tersebut dapat menjadi catatan buruk karena semestinya agama itu dapat menyerukan pada kedamaian.

Maka, dalam rangka menangkal radikalisme yang sering dikaitkan dengan Islam, umat Islam perlu menunjukkan bahwa Islam tidaklah sama dengan yang dipersepsikan masyarakat sebagai agama yang keras dan menyukai peperangan. Maka, perlu berbagai pendekatan dari berbagai perspektif untuk memaknai Islam yang sebenarnya. Termasuk diantara pendekatan tersebut adalah pendekatan sejarah. Sehingga melalui penelusuran sejarah, umat Islam akan semakin memahami antara teks dan konteks, terutama dalam hal penafsiran ayat al-Qur'an.

Kepemimpinan Nabi Muhammad di negara Madinah merupakan simbol keberhasilan Nabi Muhammad dalam membentengi lahirnya radikalisme melalui kebijakan dan pendekatan dalam berbagai peran. Sebagai seorang pemimpin negara dapat menggunakan otoritas kekuasaannya, sebagai bagian dari masyarakat dapat menggunakan kecakapan hubungan sosialnya melalui bentuk keteladanan yang baik, saling menghargai, egaliter, menghormati pluralitas, berperadaban dan berilmu pengetahuan yang tinggi, dan lain-lain. 


\section{DAFTAR PUSTAKA}

Al-Ghazali, Ibya' Ulum al-Din, Beirut: Dar al-Kutub alIlmiyah, 2001

Artani, Hasbi, Dr., Musyawarah Dan Demokrasi, Jakarta: Gayu Media Pratama, 2001,

As-Samhudi, Wafa'ul Wafa', Vol. III

Bennet, Cristine I, Comprehensive Multicultural Education: Theory and Practice, USA: Simon \& Schuster Company, 2008

Berry, David, Pokok-Pokok Pikiran dalam Sosiologi, Jakarta: Raja Grafindo Persada, 1995

Cook, David, Understanding Jihad, California: University of California Press, 2005

Culla, Surya, Adi, Masyarakat Madani: Pemikiran, Teori dan Relevansinya Dengan Cita-cita Reformasi, Jakarta:Raja Grafindo Persada, 2002

Engineer, Ali, Asghar, Liberasi Teologi Islam: Membangun Teologi Damai dalam Islam, Yogyakarta: Alinea, 2004

Esposito, John L., The Future of Islam, Oxford: Oxford University Press, 2010

Findley, Paul, Silent No More, USA: Amana Publications, 2003

Gaus, Ahmad, AF, Masyarakat Madani Warisan Nabi Muhammad Saw., Dalam Nurcholis Majid, Kehampaan Spiritual Masyarakat Modern : Respon dan Transformasi NilaiNilai Islam Menuju Masyarakat Madani Jakarta : Media Cita, 2000

Haekal, Muhammad, Husain, Sejarah Hidup Muhammad, Jakarta: Litera Antar Nusa, 1990, Cet. Ke-12

Haikal, Husein, Muhammad, Al-bukumat al-Islamiyyat, Mesir : Dar al-Ma'arif, t.th.

Hakim, Nur, Moh., Sejarah Peradaban Islam, Yogyakarta: UMM Pers, 2011

Husaini, Adian, Hegemoni Kristen-Barat dalam Studi di Perguruan Tinggi, Jakarta: Gema Insani, 2006

Iberani, Syarif, Jamal, Mengenal Islam, Jakarta: El-Kahfi, 2003 
Khalid, Muhammad, Khalid, Syaikh, 5 Khalifah Kebanggaan Islam, Jakarta: Akbar Media, 2011

Lash, Scott, Featherstone, Mike (ed.), Recognition and Difference: Politics, Identity, Multiculture, London: Sage Publication, 2002

Majid, Nurcholis, Kehampaan Spiritual Masyarakat Modern: Respon dan Transformasi Nilai-Nilai Islam Menuju Masyarakat Madani Jakarta : Media Cita, 2000 , Islam Kerakyatan Dan Keindonesiaan, Bandung : Mizan, 1994, Cet. Ke-4

, Menuju Masyarakat Madani,dalam Jurnal Ulumul Qur'an No. 2/VII/ 1996

M.A. Sallomi, Perang Global Melawan Terorisme dan Tragedi Kemanusiaan, Depok: Lentera Press, 2015

Nasir, Sahilun A., Pemikiran Kalam:Teologi Islam, Jakarta: Raja Grafindo Persada, 2010

Nasution Harun, Islam Ditinjau Dari Berbagai Aspeknya, Jilid I. Jakarta : UI Press : 1985, Cet ke 5

Ma'arif, Syafi'I, Ahmad, Piagam Madinah dan Konvergensi Sosial dalam Pesantren, no 3 / vol III / 1986, Jakarta : P3M, 1986

Maryam, Siti dkk (ed.), Sejarah Peradaban Islam,Yogyakarta: Lesfi, 2003

Shihab, Alwi, Islam Inklusif, Bandung: Mizan, 1999

Sjadzali, Munawir, Islam dan Tata Negara, Jakarta: UI Press, 1990

Supriyadi, Dedi, Sejarah Peradaban Islam, Bandung: Pustaka Setia, 2008

Pulungan, Suyuthi, J., Prinsip-prinsip Pemerintahan dalam Piagam Madinah: Ditinjau Dalam Pandangan al-Qur'an, Jakarta: Raja Grafindo Persada, 1996

Umari, Dhiya'uddin, Akram, Masyarakat Madani: Tinjanan historis Kebidupan zaman Nabi, Jakarta: Gema Insani Press, 1999

Usairy, al-Ahmad, Sejarah Islam: Sejak Zaman Nabi Adam bingga Abad XX, Jakarta: Akbar Media, 2009 
Inayatul Ulya

Weber, Max, The Theory of Social and Economic Organisation, New York: Free Press, 1947

Yatim, Badri, Sejarah Peradaban Islam, Jakarta : Raja Grafindo Persada : 2005 